\title{
Valuing the Potential of Non-timber Forest Products in Financial Valuation of Savannah Formation in Sudanian Region
}

\author{
Fifanou G. Vodouhe ${ }^{1,2}$, H. O. Dossou-Yovo ${ }^{2, *}$, Flora J. Chadaré ${ }^{3}$, Nancy Gélinas ${ }^{4}$, \\ Achille E. Assogbadjo ${ }^{2}$, Ousmane Coulibaly ${ }^{5}$ \\ ${ }^{1}$ School of Wildlife and Protected Areas Management, University of Parakou, Benin \\ ${ }^{2}$ Laboratory of Applied Ecology, Faculty of Agronomic Sciences, University of Abomey-Calavi, Benin \\ ${ }^{3}$ National School of Agricultural Sciences and Technology, Ketou Agriculture University, Benin \\ ${ }^{4}$ Department of Wood Science and Forest, Faculty of Forestry, Geography and Geomatics, University of Laval, Canada \\ ${ }^{5}$ International Institute of Tropical Agriculture, Benin
}

Copyright $\bigcirc 2016$ by authors, all rights reserved. Authors agree that this article remains permanently open access under the terms of the Creative Commons Attribution License 4.0 International License.

\begin{abstract}
This study assesses the financial value of one hectare of savannah vegetation in Sudanian region of West Africa based on the potential extraction of Non Timber Forest Products (NTFPs). Our methodology provides multiple estimations of NTFPs production from each species for two years and also takes into account variation in NTFPs prices. Given the regeneration capacity of harvested species for some NTFPs such as bark or root, we presented the annual financial value of revenue from NTFPs in contrary to some studies which determined their net present value. Results showed that the Net Annual Value of NTFPs collection is US $\$ 368 \mathrm{ha}^{-1}$ and would justify the interest of sustainable use of these resources. The most valuable products of the Pendjari Biosphere Reserve savannah were species leaves (US\$164 ha ${ }^{-1}$ ) followed by fruits (US\$89 ha ${ }^{-1}$ ) and roots $\left(\right.$ US $\left.\$ 78 \mathrm{ha}^{-1}\right)$. However, the Net Annual Value determined here is the potential value of the Sudanian savannah in NTFPs. The NTFPs financial valuation made in this study provided a useful details for comparing alternative land use practices. In view of the sustainable use of natural resources, a NTFP focused management system could be considered economically viable management option. However, they cannot be sustainability harvested in absence of careful species selection, yield studies, monitoring of regeneration and harvesting adjustments. Therefore, there is a need to know more about useful species availability, biology and reaction to harvesting impact, especially for those exploited for their roots, flowers or fruits.
\end{abstract}

Keywords Land Use Option, NTFP, Financial Valuation, Savannah Vegetation, West Africa

\section{Introduction}

The Earth Summit in 1992 led to increasing political attention to environmental problems resulting from global deforestation [1]. To mitigate this situation, many efforts were undertaken to conserve forests. But in many part of the word, these efforts, mainly based on a strictly natural science orientation, have experienced failure [2]. This failure can be explained in part by the fact that the conservation issue has not only ecological considerations. Decisions on logging, management or conversion of forestlands are most frequently determined on economics criteria such as the demand for timber, for agricultural land or the need to export forest products to earn foreign exchange [3].

Moreover, valuation of tropical forests has been traditionally based on a financial appraisal of its timber stock [4]. Empirical research on non-market forest benefits in the latter case has focused on recreational and existence values held by urban consumers. This spurred the development of non-market estimation techniques appropriate to such values [5]. And yet, in developing countries, forest values related to production and subsistence remain relatively important. Rural communities living in and around forest areas often rely heavily on Non-Timber Forest Products (NTFPs) for both subsistence and cash income $[5,6]$.

With changing political economy of forest resources around the world, benefits of NTFP are increasingly discussed in valuing tropical forests [7]. Several studies therefore argued in favour of NTFP focused forest management to reach sustainability that can reconcile economic, cultural and ecological values of tropical forests $[8,9]$. A basic premise is that if proper economic values are assigned to biodiversity, then rational decisions are possible, especially in the case of resources such as forests, which 
have alternative land use options $[10,11,12]$. Therefore, valuation will help society make informed choices about the trade-offs [13].

Furthermore, the majority of NTFPs valuation made so far are from Latin America. However, the results obtained from these studies cannot be extended to all tropical settings [14]. The value of any single site will depend on many factors of which the useful species richness at the local level, the extent of NTFPs knowledge in the area or the proximity of markets $[15,6]$. Therefore, an assessment of NTFP stocks in Africa and Asian region is essential where different forest types, harvesting methods and economies ascribe different values to the products and services from forests [see review of 4]. This study will fill in this gap by estimating valuation of NTFPs in Benin savannah (West Africa). Results from this study which has been carried out within Pendjari Biosphere Reserve could help managers and local people know the financial potential of NTFPs and make efficient land-use decisions.

The National Park of Pendjari which is part of the Pendjari Biosphere Reserve is the most important protected areas in Benin. After its notification as a Game Reserve in 1954, upgraded to a National Park in 1961 and Biosphere Reserve in 1986, the Reserve dwellers have still retained much of their traditional lifestyles and had extensive knowledge of the wildlife resources of the area [16]. Moreover, despite the ban of CENAGREF (Centre National de Gestion des Resources Forestières: the institute in charge of the Pendjari Biosphere Reserve management) to log or converse reserve land to large-scale agriculture, population are steadily motivated to continuous. They don't understand the well-being of sustainable natural resource exploitation that advocate responsible in charge of this reserve. Knowing that in Africa like in other parts of the world, establishment and maintenance of protected areas have increasingly been regarded as essential for stemming the habitat loss and preserving the exceptional rates of plant and animal endemism, it urges to develop strategies which can help assume their sustainability [17]. Indeed, putting values to NTFPs which often do not enter monetary economic system would allow foresters, local communities and policy makers to choose an appropriate mix of outputs of timber, non-timber and environmental benefit while dealing with forest land [4].

Our study determined the importance of NTFPs in the financial valuation of savannah formation of the Pendjari Biosphere Reserve and estimated the value of 1 ha of savannah formation of the Pendjari Biosphere Reserve based on returns from NTFPs. This savannah financial valuation determination was done considering only its use value. Those values ascribed to natural resources such as option value (future direct and indirect uses) indirect use value (e.g. watershed protection, nutrient cycling, air pollution reduction, micro-climatic regulation, and carbon storage) and non-use value (biodiversity, heritage, intrinsic worth and bequest value) were not considered. By describing the diversity of NTFPs used in the Pendjari Biosphere Reserve and estimating financial value of Pendjari savannah in NTFPs, our study becomes relevant to help increase local community awareness on the importance of biodiversity conservation.

\section{Non Timber Forest Products Valuation Methods: Per Hectare Economic Returns}

Since many critics were directed at ecological negative impacts of agriculture and livestock production in tropical forest areas, more attention has shifted to the economic value of NTFPs. Studies are beginning to demonstrate that the sustainable extraction of these resources may provide significant benefits to local people [18, 14, 4].

The first study which changed the world's perception of NTFPs economic values goes back to Peters et al [18]. Their study in Mishana (Peru) combined botanical survey data from a 1-ha forest plot with monthly retail prices for fruits and latex in the Iquitos market. The gross annual per hectare value of fruits and latex was estimated at US\$ 650 while the time-discounted net present value of present and future harvests of these products alone was US\$ 6330 for the single hectare; and the authors concluded that the extraction of NTFPs for sale in local markets in Iquitos, Peru, was more profitable than timber harvesting [18]. However, this study has been the target of a scattered academic critique [14, 19, 20]. Some authors point out concerns about the objections to the underestimation of post-harvest losses and marketing costs of perishable NTFPs, and to the assumption of an infinite time horizon with a low discount rate $(5 \%)$ in a situation in which land tenure and market insecurities abound[20].Doubts were also raised about the generality of results extrapolated from the chosen location and whether the density of fruit trees was typical for the Amazon forest[21, 20]. Moreover, Peters et al [18]looked at potential values of NTFPs based on inventories; while further studies have emphasized that realized production is generally much lower [see 22 review]. To correct these uncertainties and reveal a real NTFPs values, Sheiland Wunder [20] advised that series of questions should be asked about any landscape valuation study. These concern the objectives and definition of the study, the uncertainties involved (i.e., omissions, sampling concerns, methodological biases, and errors), contexts, extrapolation, generality, and ultimate interpretation.

In this way, some years after Peters and colleagues' research, Grimes et al [14] published a study on forest economic values in Ecuador. Their work improved Peters et al [18] methodology by developing separately valuing trees on an individual basis, rather than at a per species level. This allows them to better account for the wide variations in production levels and harvesting costs among individual trees of the same species. Indeed, in order to estimate the 
annual yield of potentially valuable fruit-producing trees, they surveyed each tree with at least two groups of guides. This provided them multiple estimations of the production from each tree. To further ensure that the reported sustainable collection rates are ecologically sound, they reduced the reported harvest levels by $25 \%$ to take into account losses for wildlife, spoilage, and regeneration. To supplement their field and market data, they interviewed several marketing actors who regularly used the NTFPs found in the plots.

However, according to Sheiland Wunder [20], these studies fail to consider many other cautions. For example, a single plot, such as used by Peters et al [18], is inadequate as an objective basis for generalization. Objective replication in space is required for spatial generalization, whereas replication in time is similarly required for formal temporal generalization [20]. Mahapatra and Tewari [4] in their valuation of dry deciduous forest of India addressed space concern by investigating 12 sample plots in two districts but this study didn't take into account the temporal uncertainty revealed by Sheiland Wunder[20].In the present study, our methodology addressed this issue and many other concerns revealed by Sheiland Wunder (sampling concerns, methodological biases, results extrapolation, etc.).

\section{Methods}

\subsection{Study Site}

The Pendjari Biosphere Reserve is located in the north west of the Benin $\left(10^{\circ} 30^{\prime}\right.$ to $11^{\circ} 30 \mathrm{~N} ; 0^{\circ} 50^{\prime}$ to $\left.2^{\circ} 00^{\prime} \mathrm{E}\right)$ close to the border with Burkina Faso Republic. It is bordered in south-west and south-east respectively by national highway Tanguiéta-Porga $(61 \mathrm{~km})$ and country road Tanguiéta-Batia $(42 \mathrm{~km})$. In the North and East, the River Pendjari forms a natural border of the Pendjari Biosphere Reserve that in the North is also the country's border to Burkina Faso [23, 24] (Fig. 1). Apart Atakora chain (400-513 m above sea level) in the South, the topography of the reserve is mostly ranges between $150-200 \mathrm{~m}$ above sea level [25].

The Pendjari Biosphere Reserve is established in tropical climate area in the Sudanian region with a seven months dry period. The mean annual precipitation is $1,000 \mathrm{~mm}$ with tendency in fall beginning from 1950. Most of the rain is falling during a period between late May and early October. The mean annual temperature is $27^{\circ} \mathrm{C}$ [26].

The vegetation of the Pendjari Biosphere Reserve is a mixture of different savannah types, mostly open shrub and tree savannah [16, 26]. Small islands of dry forests are situated in the areas of former villages. Tree savannahs are dominated by genus Combretum, Terminalia (Combretaceae) and Acacia (Mimosaceae) while in flooded areas they are Mitragyna inermis, Acacia sieberiana and Terminalia macroptera in swampy savannah [27]. The Poaceae is the most representative family in all herbaceous stratums except gallery forest of Bondjagou. The main grass genera are Andropogon and Hyparrhenia [28]. In the periphery of the Pendjari Biosphere Reserve the landscape is dominated by fields and fallows.

The border of the Pendjari Biosphere Reserve is lined with about 20 small villages. Population density in this area is low (13 inhabitants per $\mathrm{km} 2$ ) compared with the whole country and it is estimated at 30,000 inhabitants [29].

\subsection{Data Collection and Analysis}

Firstly, to describe the link between plant botanical families, organs harvested and uses, Principal Component Analysis was applied to a matrix of frequencies of species recorded within each families, organ collected and different uses. The species' botanical families were projected in the system axis defined by the principal components in order to describe the species according to the organ exploited and uses.

Secondly, to estimate the economic value of savannah, we measured NTFPs yield from one hectare and calculated its monetary value. The study was carried out on 12 permanent sample plots $(100 \times 100 \mathrm{~m})$ in savannah formation of the Pendjari Biosphere Reserve for two years (Fig. 2). The collection of data through two years provided multiple estimations of the production from each tree and also helped to take into account NTFPs prices variation. It permitted to address the temporal issue shown by Sheil and Wunder[20].The plots were sampled randomly using the Global Positioning System (GPS) and the vegetation map of the Pendjari Biosphere Reserve with the help of the reserve staff. This sampling method permitted to mitigate the probable effect of unequal distribution of plant diversity through the reserve on the NTFPs financial valuation assessment. The high number of plots investigated contrary to previous studies makes us comfortable for results generalization $[18,4]$. The idea of choosing savannah in the Pendjari Biosphere Reserve is motivated by its richness in species which produce NTFPs and it's the main formation in the reserve [29].Given the regeneration capacity of harvested species for some NTFPs such as bark or root, we presented the annual financial value of revenue from NTFPs in contrary to some studies which determined their net present value [18, 14, 4].

For NTFPs financial value estimation, within sampled plots we enumerated in collaboration with local people all trees of $10 \mathrm{~cm}$ or greater DBH (Diameter at Breast Height). We recorded from all individuals data on DBH, height and crown size. To estimate the yield of fruits and flowers, we selected some branches of each tree within the sample plot, harvested fruits or flowers as done by local communities, weighted and used theses samples for the whole tree production estimation. Species which were not in production were marked and their production estimated in the same manner in appropriate seasons. Concerning bark valuation, 
we measured the height of the trunk of species from which this organ is exploited and estimated the quantity of bark likely to be harvested. The same thing was done for species used for their roots. In addition, to enumerate useful herbs and bushes of less than $10 \mathrm{~cm}$ DBH we marked in each plot 5 quadrants of $10 \times 10 \mathrm{~m}$ size (Fig. 2). Within the quadrants, we harvested and weighted all herbs and bushes used for their leaves, flowers, fruits, barks or roots during appropriate seasons. We determined the average quantity of NTFPs harvested from each species identified within the 5 quadrants and extrapolated to the plots. To make sure that the collection is ecologically sound and sustainable and to take into account losses for wildlife, regeneration and wastage, we reduced by $25 \%$ the harvest levels for each tree, shrubs and herbs [14].
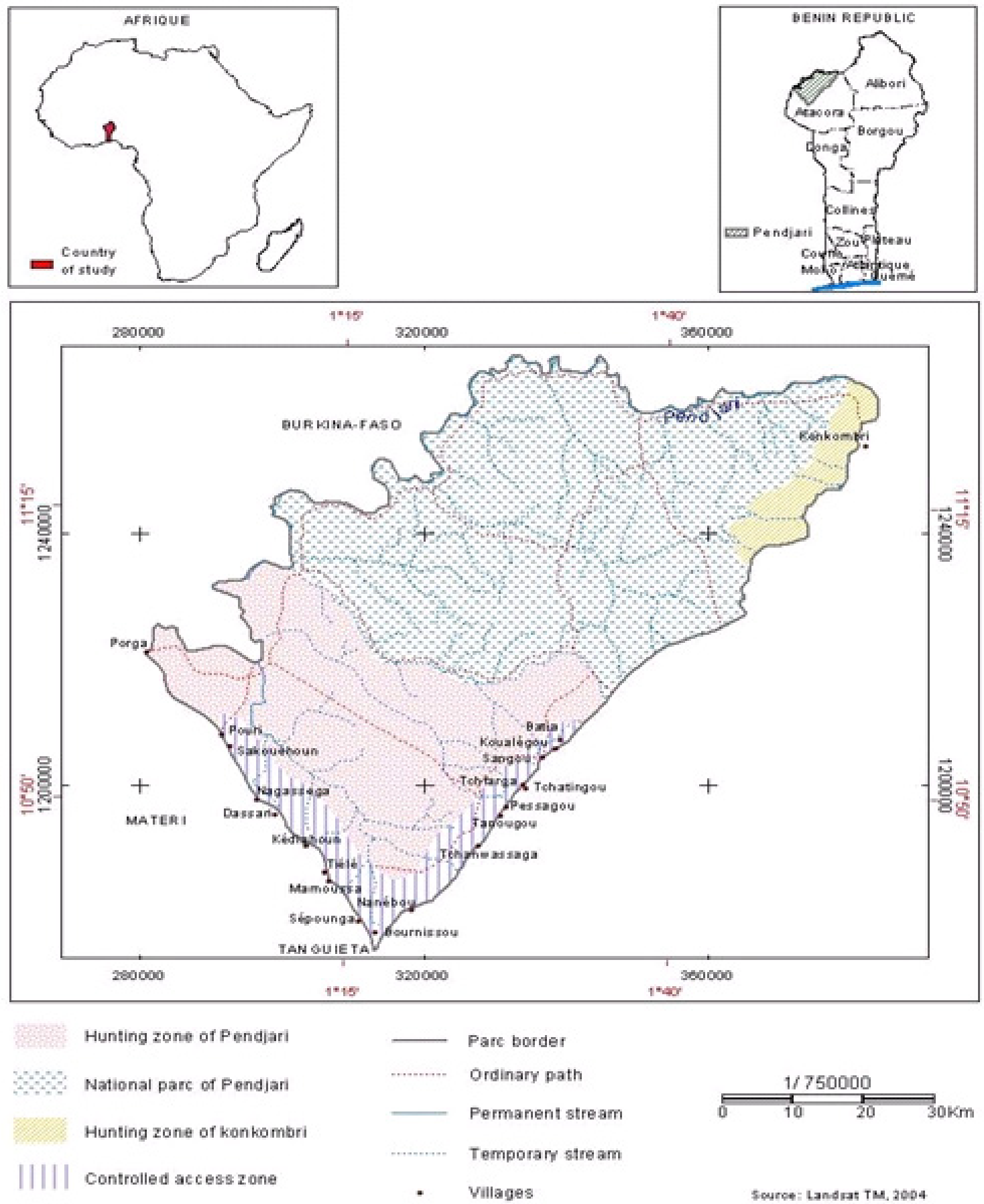

Figure 1. Maps showing the location of the study country Benin in West Africa as well as the study area Biosphere Reserve of Pendjari in Northern Benin. The Atakora chain is the southern border of the reserve whereas it is the Pendjari River which constitutes its north- western border.. 


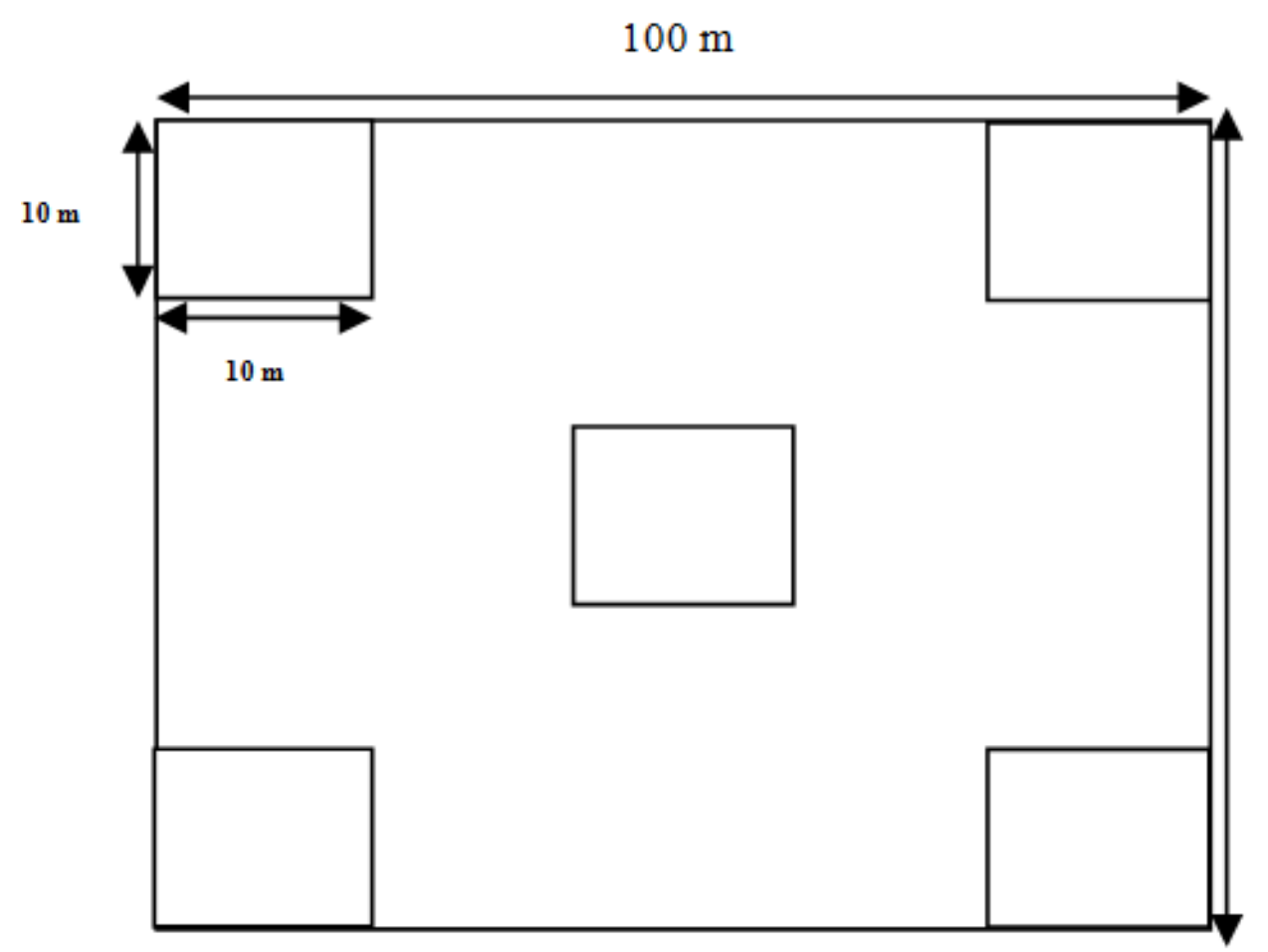

$100 \mathrm{~m}$

Figure 2. Sampling plots presentation

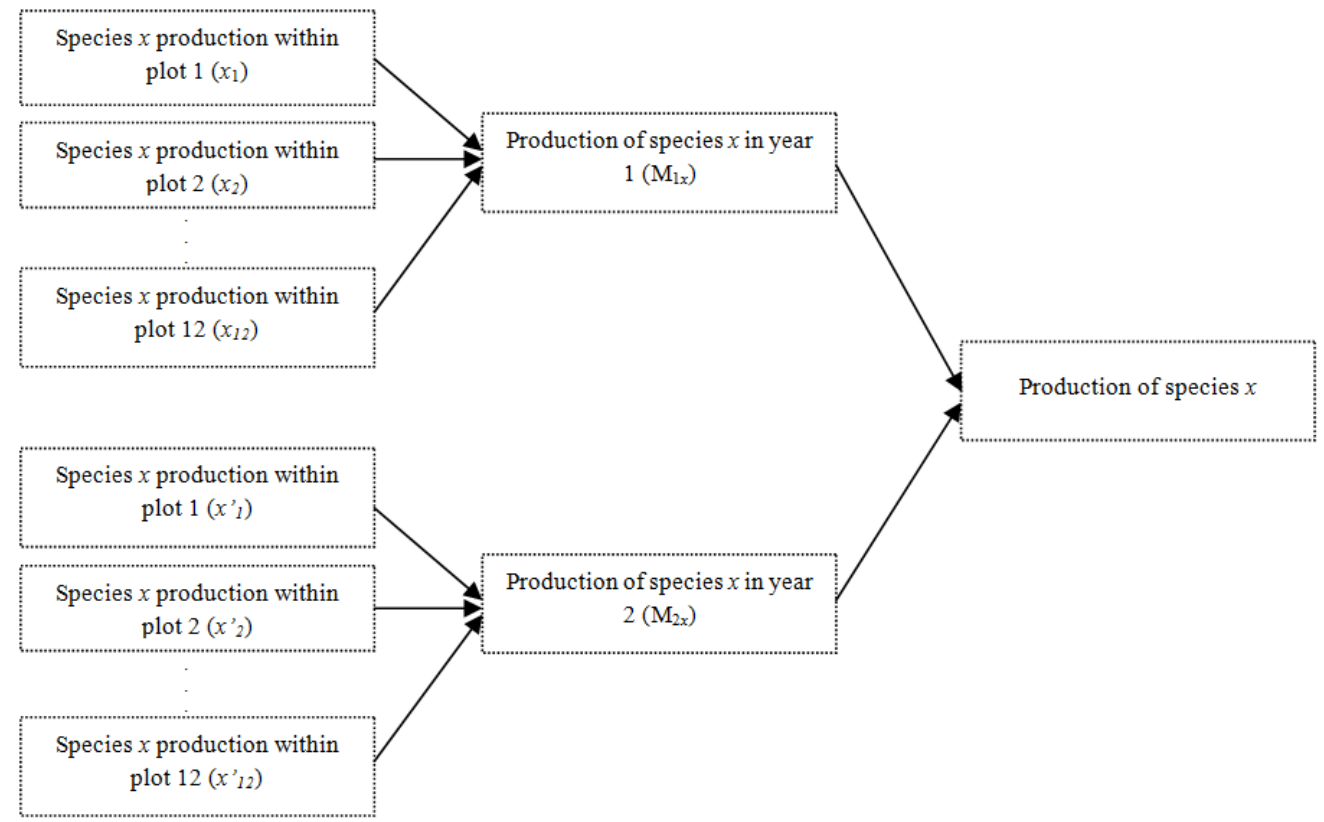

M1x and M2x are respectively the production of species $\mathrm{x}$ during year 1 and 2 . There are obtained by summing up the production for each individual of species within the plots

$\mathrm{x} 1$ and $\mathrm{x}$ ' 1 are respectively the production of the individual 1 of species $\mathrm{x}$ within the plot 1 during year 1 and $2 . \mathrm{M} 1 \mathrm{x}=\frac{\sum_{i=1}^{i=12}\left(x_{1}+x_{2}+x_{3}+\cdots+x_{12}\right)}{12}(1)$

Figure 3. Different steps followed to determine NTFPs production

Then, we determined for each species the mean production as shown in Fig. 3 and related equations. We collected these data by involving in the research team ten local people (ranging from 20 to 60 years old) known for their knowledge of NTFPs and familiarity with harvesting methods. During the data collection, each species identified as useful by local participant were sampled to make field herbarium and later identified taxonomically using an illustrated reference book of Arbonnier and Benin Analytic Flora $[30,31]$. We conducted the taxonomic identification of species which were not identified directly in the field at the National Herbarium of Benin, at the University of Abomey-Calavi, where all plant species known to be native to Benin are conserved as voucher specimens. To have species use validated by the local community, we used the sample of species identified within the plots and asked 
participants during focus groups discussion on their knowledge about the species. In total, we organized 60 focus group discussions through the two years and about twenty men and women participated in each focus group discussion. Focus groups participants were randomly selected basing on their knowledge about useful species and their willingness to be involved in the study.

To assess the market value and cost of NTFPs extraction, we visited every two weeks the five most important markets in the study area (Tanguiéta, Matéri, Dassari, Porga and Tanongou) for ascertain the market prices of various products marketed. In our study area, the NTFPs commercialization is not controlled. We recorded the trading price for each item by the way of market observations. For NTFPs valuation we considered the selling cost obtained from collectors to minimize error due to processing or other cost estimation. To do it, we bought each marketable species product from collectors and weighted to know the price per unit weigh $(\mathrm{kg})$. The prices were estimated for each species at different time during the year and we used the annual mean price to calculate each NTFP gross revenues using equation 2. For multiuse species, we determined the gross revenue by summing up the trading value of each NTFP harvested from the species.

$$
\mathrm{T} 1 \mathrm{x}=\mathrm{M} 1 \mathrm{x} * \mathrm{P} 1 \mathrm{x}
$$

Let $\mathrm{T}_{I x}$ be the gross revenue obtained from species $x$, $M_{l x}$ be the production of species $\mathrm{x}$, and $\mathrm{P}_{l x}$ be the annual mean price of one kilogram of NTFP collected from species $x$ during year 1 .

In the study area, the major cost involved at the producer level is the time spent to collect NTFPs. People don't need to pay any royalty before to collect NTFPs. To calculate collecting time cost, we estimated by way of focus group discussions and field observation information on trips made to collect the item; hours spent on harvesting site and transport costs to home and from home to selling place. We obtained the total cost of harvesting by multiplying local wage rate (1500 FCFA/man-day) with the time required for extraction, transportation and sale (US\$ $1=450$ FCFA). Then, the net annual market value $\left(\prod_{l x}\right)$ of NTFP obtained from species $x$ during year 1 was determined as followed:

$$
\prod_{l x}=\mathrm{T}_{l x}-\mathrm{C}_{l x}
$$

$\mathrm{With}_{1 \mathrm{x}}$ the gross revenue obtained from species $\mathrm{x}$ during year $1 \mathrm{C} 1 \mathrm{x}$ the total cost involved in species product collection during the year 1

The net annual value ( $\Pi 1)$ of NTFPs collected in year 1 on one hectare was:

$$
\prod_{1}=\prod_{l x}+\prod_{l y}+\ldots+\prod_{l n}
$$

with $\mathrm{n}$ the total number of species identified $\prod 1 \mathrm{x}, \Pi 1 \mathrm{y}$ and $\prod 1 \mathrm{n}$ the net annual market value of species $\mathrm{x}, \mathrm{y}$ and $\mathrm{n}$ during year 1 . The mean net annual value $\left(\prod \mathrm{t}\right)$ of NTFPs collected in 1 ha was:

$$
\prod_{t}=\left(\prod_{1}+\prod_{2}\right) / 2
$$

with $\prod 1, \Pi 2$, respectively the net annual market value of NTFPs during year 1 and 2

To estimate the net annual value of non-marketed NTFPs, we used the Contingent Valuation Method with open question. The Contingent Valuation Method is an example of a stated preference method which has been widely used to elicit people's preferences, especially in cases where there is no real market for a good [32, 33, 34, 35].Like any other economic methodology, contingent valuation has its limitations [36]. One of the main criticism that economists have leveled at the contingent valuation method has been that such willingness to pay estimates are inflated because respondents are prone to say yes too easily, perhaps just to please the interviewer (enumerator bias). Researchers have developed a number of ways to reduce this yea-saying tendency [37]. These ways include time-to-think experiments [38]. The hypothesis is that allowing the respondent to discuss the choice with other household members permit to receive adequate answer. In our case, by conducting the contingent valuation survey during focus group discussion we allow the respondent to discuss his willingness to pay for NTFPs harvesting with other local communities members before to answer. In the Pendjari Biosphere Reserve, the major part of NTFPs used was not commercialized [6]. People directly collect species products in the vegetation and use them for their daily subsistence. Therefore, for knowing the financial value assigned to one species leaves for example, we harvested and weighted a bundled of this organ and asked local people during the focus group discussions to know which amount of money they are agree to pay to someone who accepts to harvest this quantity of leaves for them. Information was also received on the time required for extraction. The focus group discussions were conducted in such a way that one participant answer can't affect others. While the question was asked to all participants, and times were given to them to interact, answers were recorded individually. The answers were requested respectively if the extraction site is far from the house $(3 \mathrm{~km})$ or close to house (less than $3 \mathrm{~km}$ ). Harvesting sites situated at more than $3 \mathrm{~km}$ were identified by local people as too far away to go on foot. The species value was estimated by subtracting from each value attributed to the non-marketed NTFPs the total cost involved in its collection. Then the net annual market value of species $x$ for example ( $\prod^{\prime}{ }_{1 x}$ ) was obtained by summing up all values and divided by the number of responses (equation 6). This operation was done each year for non-marked species. Based on previous study in the Pendjari Biosphere Reserve which revealed that wealthier as well as poorer households were equally dependent on NTFPs [12], we assume that participant's socioeconomics characteristics cannot affect the value they ascribed to species.

$$
\begin{aligned}
\prod^{\prime} 1 \mathrm{x} & =[(\mathrm{CV} 1-\mathrm{Ct} 1)+(\mathrm{CV} 2-\mathrm{Ct} 2)+ \\
& +(\mathrm{CV} 3-\mathrm{Ct} 3)+(\mathrm{CV} 4-\mathrm{Ct} 4)] / 4
\end{aligned}
$$

Where: 
- $\mathrm{CV}_{1}$ and $\mathrm{Ct}_{1}$ are respectively the value attributed to species during available period and the total cost needed for collection if the extraction site is far from the house,

- $\quad \mathrm{CV}_{2}$ and $\mathrm{Ct}_{2}$ are respectively the value attributed to species during unavailable period and the total cost needed for collection if the extraction site is far from the house,

- $\quad \mathrm{CV}_{3}$ and $\mathrm{Ct}_{3}$ are respectively the value attributed to species during available period and the total cost needed for collection if the extraction site is close to house,

- $\mathrm{CV}_{4}$ and $\mathrm{Ct}_{4}$ are respectively the value attributed to species during unavailable period and the total cost needed for collection if the extraction site is close to house.

\section{Results}

\subsection{Non-Timber Forest Products Recorded from the Sample Plots}

During the field survey, a total of 72 species ( 27 families) were found as useful to communities in the Pendjari Biosphere Reserve (Appendix 1). The most represented family was Leguminoseae with 14 species followed by Combretaceae (nine species), Rubiaceae (six species) and Poaceae (five species). The thirteen most represented families were shown on Fig. 4. Fourteen families were represented by only one species. Species were harvested mainly for medicine $(46.2 \%)$, food $(20.5 \%)$, construction materials (11.5\%), ceremony $(8.3 \%)$ and other uses (toothbrush, art object: $13.5 \%$ ). The majority of species recorded $(65.28 \%)$ were multiuse species. The most harvested organs were leaves $(32.2 \%)$ followed by roots (30.2\%), bark (26.8\%), fruits $(9.3 \%)$ and flowers $(0.9 \%)$.

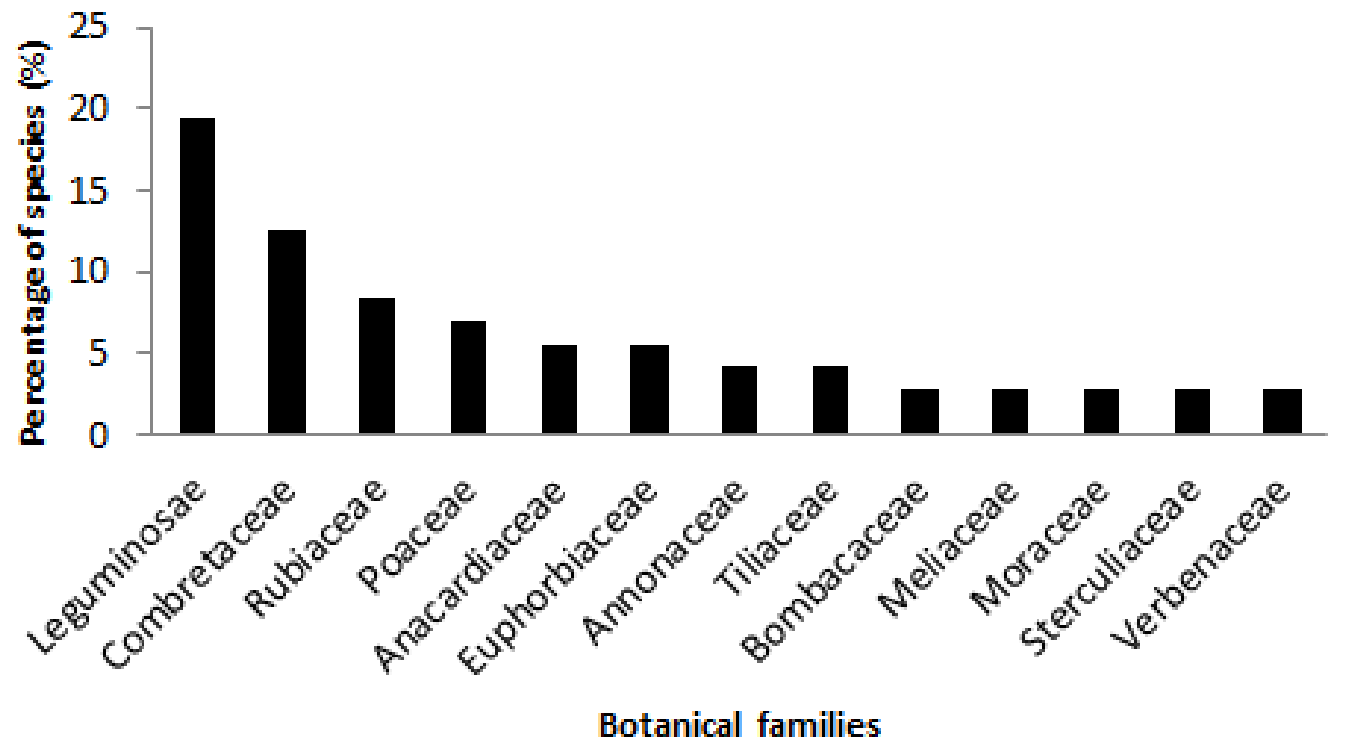

Figure 4. The most represented families in NTFPs identification. The number of species identified within these families varies from 2 to 14 species 


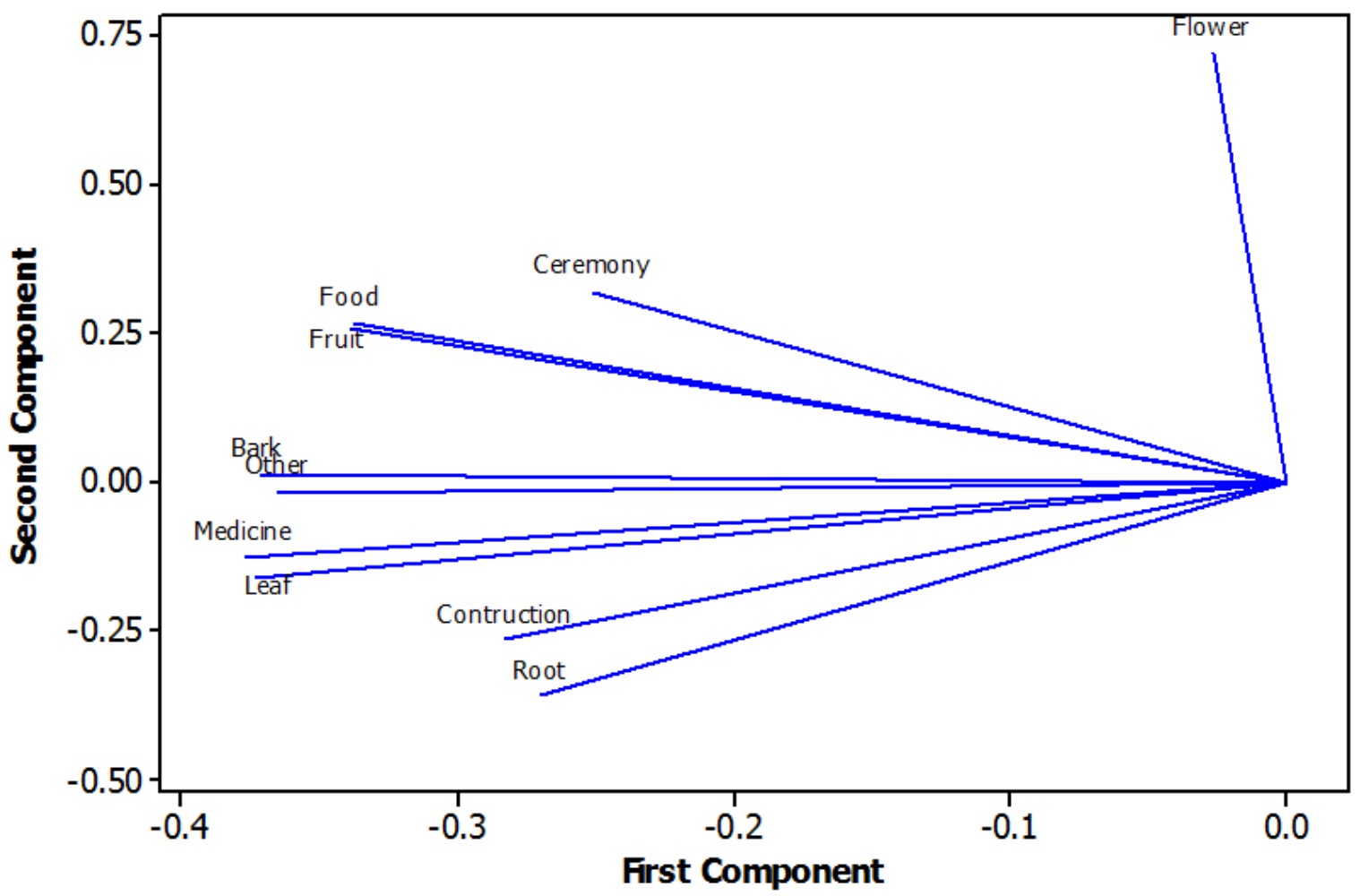

Figure 5. Projection of the different parts harvested from the species and their uses

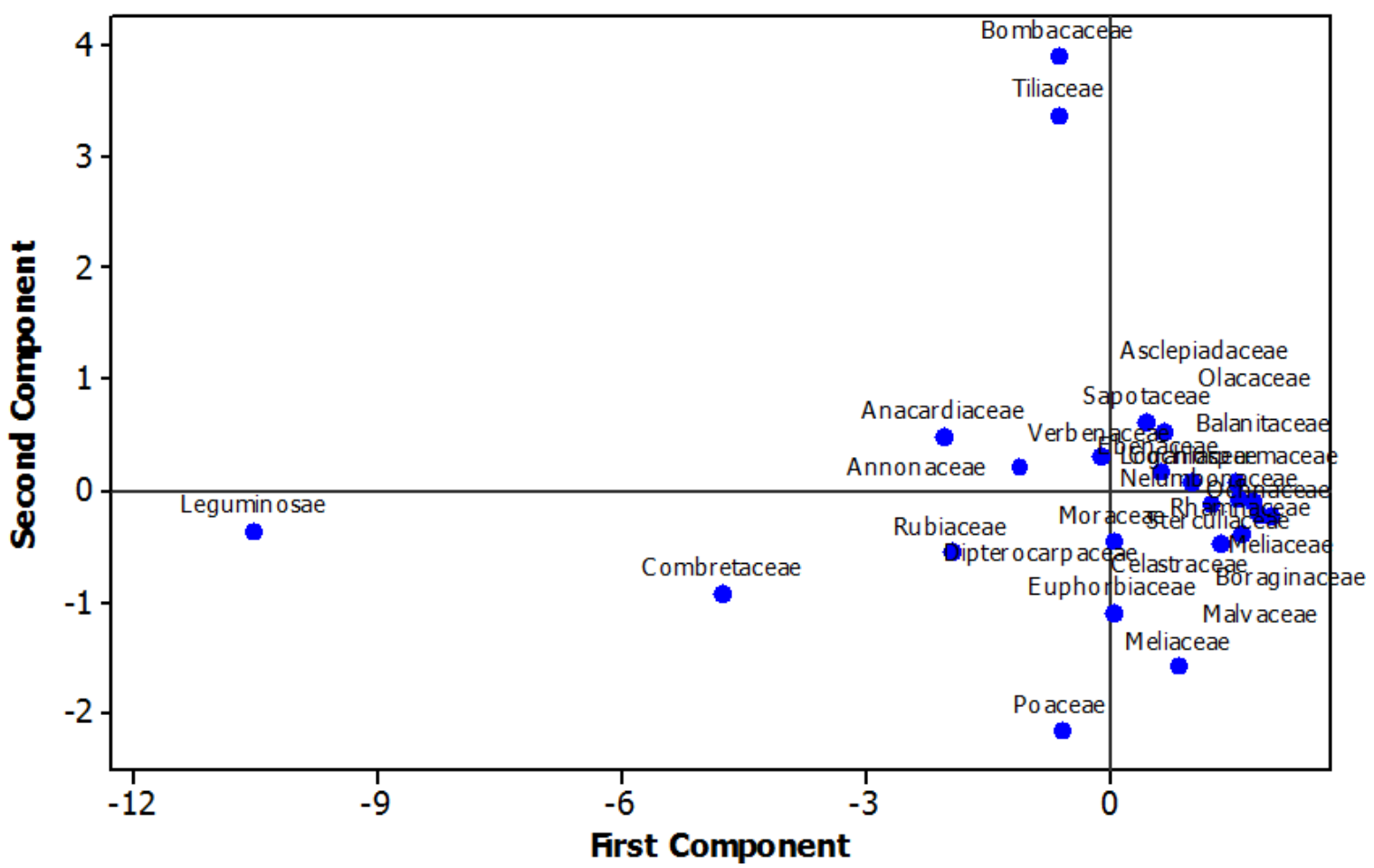

Figure 6. Projection of the species' families in the system axis defined by the principal components

Results of the Principal Component Analysis performed on the plant organ harvested and their uses showed that the first two axes explained $79.5 \%$ of the overall information on species parts (Fig. 5). We noticed from this figure that species exploited for their leaves, fruits and bark were mainly used for medicine, food, toothbrush and art objects (axis 1). Axis 2 shows that the species harvested for flowers were used for ceremonies in contrary to those harvested for roots.

The projection of the species' families in the system axis defined by the principal components (Fig. 6) shows that species of Combretaceae and Leguminosae families were harvested for their leaves, fruits and bark used for medicine, food, toothbrush and art objects. Species of Bombacaceae 
and Tiliaceae families were harvested for flowers and were mainly used in traditional ceremonies.

\subsection{Financial Valuation of Non-Timber Forest Products}

The Net Annual Value of the Pendjari Biosphere Reserve savannah formation in NTFPs $\left(\prod_{t}\right)$ was estimated to be 165 $817 \pm 9127 \mathrm{FCFA} / \mathrm{ha}\left(\mathrm{US} \$ 368 \mathrm{ha}^{-1}\right.$ ) (Appendix2). The ten most valuable species were showed on Fig. 7. They concentrated $40 \%$ of the global value of the savannah vegetation and were harvested for various purposes. $H$. involucrata, A. gayanus and $P$. pedicellatum were locally used in house construction to fence houses or to thatch roofs while their roots were used as medicine. The fruits harvested from $P$. biglobosa and $V$. paradoxa are processed and used in the daily diet of the local people. Their barks are also used in traditional medicine. V. doniana and T. indica fruits were harvested and consumed as fresh fruits but the most important product collected from $V$. doniana was its young leaves used as vegetable in human diet. C. glutinosum, $C$. planchoni and T. laxiflora were mainly used in traditional medicine. Only $48 \%$ of NTFPs identified within the plots were commercialized on local markets. Indeed, the Net Annual Value of NTFPs commercialized on the markets was estimated to be $79595 \pm 3345 \mathrm{FCFA} / \mathrm{ha}$ (US\$ $176 \mathrm{ha}^{-1}$ ) versus $86225 \pm 10769 \mathrm{FCFA} / \mathrm{ha}$ (US\$ $192 \mathrm{ha}^{-1}$ ) for non-commercialized species.

The most valuable products of the Pendjari Biosphere Reserve savannah are species leaves $(74,002 \pm 478$ FCFA/ha $)$ followed by fruits $(40,216 \pm 457 \mathrm{FCFA} / \mathrm{ha})$ and roots $(35,073 \pm 514$ FCFA/ha) (Fig. 8).

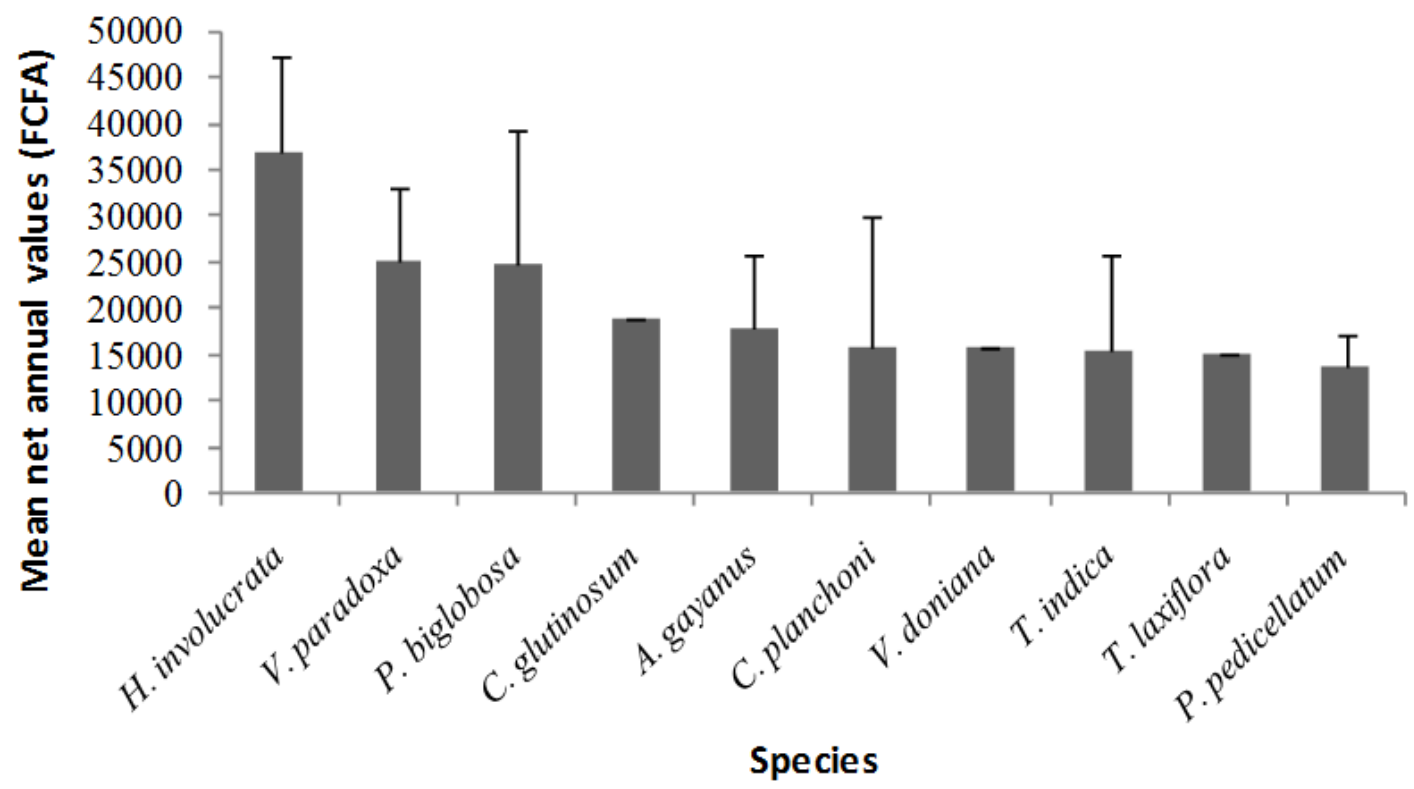

Figure 7. The ten most valuable species within savannah by the Pendjari Biosphere Reserve people

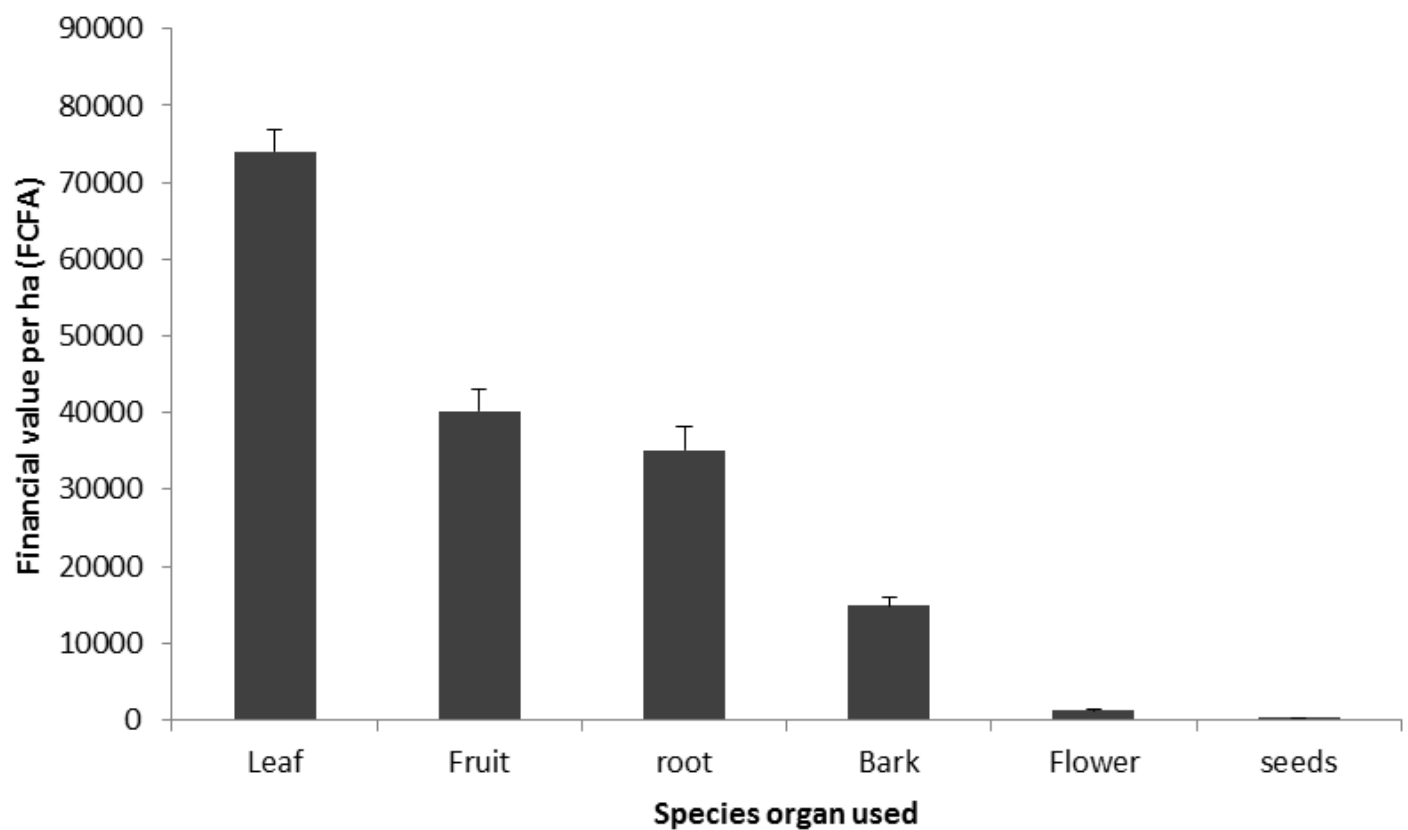

Figure 8. Valuable products within the Pendjari Biosphere Reserve savannah vegetation 


\section{Discussion and Conclusions}

This study helped peasants know the benefits that they could gain in sustainable use of natural resource exploitation. It's a powerful tool to help the park responsible to increase local community awareness about biodiversity conservation within it. Even if the methodology used has already been under criticisms [e.g., 39, 21, 41, 19, 20], it provides a useful economic benchmark for comparing alternative land use practices and management options for the Pendjari Biosphere Reserve. Our methodology improved those used in previous studies $[18,14,4]$ by providing multiple estimations of NTFPs production from each species through two years and also taking into account NTFPs prices variation. The high number of plots investigated also makes us comfortable for results generalization. Indeed, using our methodology, the financial value of savannah in NTFPs may depend on several factors from which the floristic composition of the vegetation, species density, people dependence on wild species and market demand for various plant $[20,4,41]$.We address the two first issues by randomly sampling 12 plots of one hectare to estimate the financial valuation of savannah in NTFPs. Therefore, the standard error observed reflects the variation in the level of production from tree to tree and from year. From one year to another, some species production varies according to the climate, bush fire, and species phenology.

\subsection{NTFPs Importance in Financial Valuation of Sudanian Savannah Vegetation}

The study proved that NTFPs had important value in savannah financial value estimation. NTFPs have the potential to improve the livelihoods of people who depend on them for their basic needs and cash income. The economic importance of NTFPs is also perceptible considering the cost needed to collect them. A part the time spent to harvest, transport or sell NTFPs products, people don't need to engage any additional charge before getting benefit from these products. However, they need to harvest species products on a sustainable basis.

The net annual value of NTFPs harvesting in the Pendjari Biosphere Reserve (US\$ $368 \mathrm{ha}^{-1}$ ) is higher than those obtained in India (net annual value $=$ US\$ $286 \mathrm{ha}^{-1}$; [4]) and Equador(US\$ $115 \mathrm{ha}^{-1}$; [14]) but lower than the sustainable fruit and latex harvest in the Amazonian rain forest (US\$ 650 $\left.\mathrm{ha}^{-1} ;[18]\right)$. As shown by Croitoru[41], the variations observed are influenced by various factors, such as the differences in the studies' objectives, methodology, assumptions, site biology, type of management and number of goods valued $[42,43]$. Contrary to previous studies $[18,14$, 4],our research recorded and determined financial values of all NTFPs within sampling plots. Indeed, in addition to marketed species, we also include in the plot financial valuation the value of non-marketed species using Contingent Valuation method. In opposite, Peters et al [18]in their study considered only commercial tree species occurring in one hectare but the high net annual value obtained may be due to their methodology based on inventories to determine the potential values of used products while other studies have emphasized that realized production is generally much lower [see 22 review]. Grimes et al[14] considered in their valuation seven fruits, three medicinal barks, and one resin while Mahapatra and Tewari[4] included in their study only tree with $10 \mathrm{~cm}$ or greater DBH producing marketable NTFPs (10 trees, four shrubs, one grass and one climber species). The limited number of NTFPs included in the two last studies could explain the lower net annual value observed.

Despite the difference in methodology to explain various values observed, the high value per hectare of NTFPs in the Pendjari Biosphere Reserve is mostly a result of grazing benefits, which alone account for about $35 \%$ of the per hectare NTFPs value. The main reason which explains this is the kind of vegetation studied. Savannah is an ecosystem characterized by the trees widely spaced. In this kind of vegetation, the open canopy allows sufficient light to reach the ground to support an unbroken herbaceous. The dominant herbaceous component of the Pendjari Biosphere Reserve is intensively used in house construction. The importance of herbaceous component in savannah vegetation is probably one of the most important factors to explain the difference observed comparing our finding with previous studies. This result is consistent with finding from Croitoru[41] who conclude when comparing the potential of NTFPs in the Mediterranean region that the average estimate for northern and eastern countries are considerably lower than southern countries where grazing is the most benefit for countries. Therefore we can conclude that the vegetation type would be determining factor in tropical vegetation valuation.

Moreover, this study didn't take into account the non-use value of the Pendjari Biosphere Reserve Savannah such as $\mathrm{CO}_{2}$ storing. Considering this value will increase sustainable NTFPs use value over other land use options such as land conservation for agriculture. Indeed, when a tree is cleared, greenhouse gas emissions are released into the atmosphere. Therefore, by accepting NTFPs sustainable uses which more protect the Pendjari Biosphere Reserve vegetation, local people could benefit from the Reduction of greenhouse gas emissions into the atmosphere due to Deforestation or forest Degradation (REDD) support. Indeed, the REDD program can economically compensate local people that decide not to cut down forests for agriculture, cattle farming, mining, and other activities, and instead conserve the standing forest by using in a sustainable way, such as low-impact forest management, ecotourism, use of NTFP, and environmental services.

However it is very important to put this NTFPs valuation into perspective. The net annual value determined here is just the potential value of the Sudanian savannah in NTFPs. All NTFPs recorded and involved in this valuation are not marketed and for those marketed; the local markets demand 
cannot covert the supply if local communities decide to considerably increase their exploitation. Indeed, despite the high NTFPs potential for improving the livelihoods of local communities who depend on them, the promotion of their exploitation are faced many difficulties. As shown by Ros-Tonen [44], among these are lack of information on potential market and marketing channels, the fragmented nature of NTFP markets, the unpredictability of the production cycles, resulting in irregular supplies. These difficulties could explain why local communities don't actually derive the high potential incomes from these products and are still interested by other use such as land conversion into agriculture although NTFPs value exceeds this land use option. Similar remarks had been made by Mahapatra and Tewari[4] who gave as reasons the seasonal nature of NTFPs which do not provide an income throughout the year, the market demand for many items which fluctuates between years causing uncertainty in demand and price and the increase in the rural population and numbers of forest users which led to reduction in the extraction and return per household.

\subsection{Implication for Conservation}

The NTFPs financial valuation made in this study provide the useful information for comparing land use practices in West Africa. Results clearly show that NTFPs could contribute importantly to local communities' economies on a per hectare basis. This finding is a powerful tool for responsible in charge of protected areas and other Non-Governmental Organization strongly involved into conservation of nature to raise awareness about the importance of their activities. Indeed, economic valuation of natural resources is very important to help people to make informed choices. And, knowing that in Africa, protected areas are the cornerstone of biological conservation, results obtained in this study will be useful tools to help park responsible to improve their management planning. Moreover, in view of the current adverse criticism on environmental impact of park land conversion into agriculture, a NTFP focused management system can be considered economically viable management option.

We agree with Ros-Tonen [44] that it will be incorrect to suggest that NTFPs can be harvested indefinitely without proper management practices to sustain their yield. In the case of the Pendjari Biosphere Reserve, we could be delighted at the thought that species are mainly used for their leaves. According to Cunningham [45], species exploited for their leaves were less vulnerable than those from which reproductive organs were harvested. However, they cannot be sustainability harvested in absence of careful species selection, yield studies, monitoring of regeneration and harvesting adjustments. Only products which can be harvested without killing the individual plants, which are abundant or which regenerate easily, offer good prospects for sustainable management [44]. Therefore, there is a need to know more about useful species availability, biology and reaction to harvesting impact, especially for those exploited for their roots, flowers or fruits.

\section{Acknowledgements}

This work was financially supported by the Rufford Maurice Laing Foundation (United Kingdom) through a grant provided to Fifanou G. VODOUHE in 2008. We are grateful to local communities who participated in this research. Our acknowledgements also go Dr. Orou G. Gaoue and Prof. Achille E. ASSOGBAJO for their helpful assistance during the research.

\section{Appendix}

Appendix 1. Species identified within plots with their families, part used and major uses

\begin{tabular}{|c|c|c|c|}
\hline Espèces & Family & Part used & Use \\
\hline Lannea acida A.Rich. S.1. & \multirow{4}{*}{ Anacardiaceae } & Leaf, bark, root, fruit & 2,3 \\
\hline Lannea microcarpa Engl. K. Krause & & Leaf, bark & $1,2,4,5$ \\
\hline Ozoroa insignis Delile & & Leaf, bark, root & 1,2 \\
\hline Sclerocarya birrea (A.Rich.) Hochst. & & Leaf, bark, root, fruit & 1,2 \\
\hline Annona senegalensis Pers. & \multirow{3}{*}{ Annonaceae } & Leaf, bark, root & $1,2,4,5$ \\
\hline Hexalobus monopetalus (A.Rich.) Engl. \& Diels & & Leaf, bark, root & 2 \\
\hline Uvaria chamae P. Beauv. & & Leaf, fruit & $1,2,5$ \\
\hline Raphionacme brownii Scott-Elliot & Asclepiadaceae & Root & 1 \\
\hline Balanites aegyptiaca (L.) Delile & Balanitaceae & Leaf, fruit, Bark, root & 1,2 \\
\hline Bombax costatum Pellegr. \& Vuillet & \multirow{2}{*}{ Bombacaceae } & Leaf, Flowers, bark & $1,2,3$ \\
\hline Adansonia digitata L. & & Leaf, bark, fruit, & $1,2,3,5$ \\
\hline Cordia senegalensis Juss. & Boraginaceae & Leaf, bark, root & 2 \\
\hline Gymnosporia senegalensis (Wight \& Arn.) Hook.f. & Celastraceae & Leaf, bark, root & 2 \\
\hline Cochlospermum planchoni Hook.f. & Cochlospermaceae & Root & 1,2 \\
\hline Anogeissus leiocarpa (DC.) Guill. \& Perr. & \multirow{2}{*}{ Combretaceae } & Leaf, bark, root & 2,4 \\
\hline Combretum collinum Fresen. & & Leaf, bark, root & $1,2,5$ \\
\hline
\end{tabular}


Combretum glutinosum Perr. Ex DC.

Combretum micranthum G.Don

Combretum nigricans Lepr. Ex Guill. \& Perr.

Pteleopsis suberosa Engl. \& Diels

Terminalia avicennioides Guill. \& Perr.

Terminalia laxilora Engl.

Terminalia macroptera Guill. \& Perr.

Monotes kerstingii Glig

Diospyros mespiliformis L.

Bridelia ferruginea Benth.

Flueggea virosa Willd.

Hymenocardia acida Tul.

Phyllanthus amarus L.

Acacia gourmaensis A.Chev.

Acacia hockii de Wild

Afzelia africana Sm.

Burkea africana Hook.

Danniellia oliveri (Rolfe) Hutch. \& Dalziel

Dichrostachys cinerea (L.) Wight \& Arn.

Entada africana (Guill. \& Perr.)

Parkia biglobosa (Jacq.) R.Br. Ex Benth.

Piliostigma thonningii (Scumach.)

Prosopis africana (Guill. \& Perr.) Taub.

Pterocarpus erinaceus Poir.

Tamarindus indica L.

Tephrosia bracteolata (Guill. \& Perr.)

Cassia sieberiana DC.

Strychnos spinosa L.

Hibiscus asper

Khaya senegalensis (Desr.) A.Juss.

Pseudocedrela kotschyi (Schweinf.) Harms

Ficus glumosa $\mathrm{L}$.

Ficus sycomorus L.

Syzygium guineense (Willd.) DC.

Lophira alata Banks ex Gaertn

Ximenia americana $\mathrm{L}$.

Andropogon gayanus Kunth

Andropogon fastigiatus L.

Hyparrhenia involucrata Stapf

Loudetia arundinacea (Hochst. Ex A.Rich.) Steud.

Pennisetum pedicellatum Trin.

Ziziphus abyssinica A.Rich.

Crossopteryx febrifuga (G.Don) Benth.

Gardenia erubescens Stapf \& Hutch.

Gardenia aqualla Stapf \& Hutch.

Gardenia ternifolia Schumach. \& Thonn.

Mitragyna inermis (Willd.) Kuntze

Sarcocephalus latifolius (Sm;) E.A.Bruce

Vitellaria paradoxa C.F.Gaertn.

Dombeya quinqueseta Cav.

Waltheria indica $\mathrm{L}$.

Grewia bicolor Juss

Grewia pubescens P. Beauv.

Grewia lasiodiscus K. Schum.

Vitex simplifolia

Vitex doniana Sweet
Dipterocarpaceae

Ebenaceae

Euphorbiaceae

Leguminosae

Loganiaceae

Malvaceae

Meliaceae

Moraceae

Nelumbonaceae

Ochnaceae

Olacaceae

Poaceae

Rhamnaceae

Rubiaceae

Sapotaceae

Sterculiaceae

Tiliaceae

Verbenaceae
Leaf, fruit, bark, root

Leaf, fruit, bark, root

Leaf, fruit, bark, root

Leaf, bark, root

Leaf, bark, root

Leaf, bark, root

Leaf, bark, root

Leaf, bark, root

Leaf, bark

Leaf, bark

Leaf, root

Leaf, bark, root

Leaf, root

Leaf, bark, root

Leaf, bark, root

Leaf, seeds

Leaf, fruit, bark, root

Leaf, bark, root

Leaf, bark

Leaf, bark, root

Leaf, fruit, bark, root

Leaf, bark, root

Leaf, bark, root

Bark, root

Leaf, bark, root, fruit Leaf

Leaf bark

Leaf, bark, root, fruit

Leaf

Bark

Bark, root

Leaf, bark, root

Leaf, bark

Leaf, bark, root, fruit

$$
\text { Leaf }
$$

Leaf, bark, root, fruit

Leaf, root

Leaf, root

Leaf, root

Leaf, root

Leaf, root

Leaf, bark, root

Leaf, bark, root

Leaf, bark, fruit

Leaf, bark

Leaf, root

Leaf, bark, root

Leaf, bark, root

Leaf, bark, fruit

Leaf, bark

Leaf, root

Leaf, bark

Leaf, flower, bark, fruit

Bark, root, fruit

Leaf, bark, root

Leaf, bark, root, fruit
1,2

1,2

1,2

2

2

2

2,5

2

$1,2,3,4,5$

2

$2,4,5$

2

2

2,5

2

$2,4,5$

$1,2,3,4$

$2,4,5$

$2,4,5$

2,5

$1,2,3$

$1,2,4$

2

1,2

$1,2,3,4,5$

2

2

1,2

1,2

2

2

$1,2,4$

$1,2,4,5$

2

$1,2,3$

2,4

2, 4

2,4

2,4

2,4

2

2,5

1,2

2

2

2

$1,2,5$

$1,2,3,5$

2

2

1,2

1,2

1,2

2

$1,2,3,5$

Food (1); Medicinal (2); Ceremony (3); Construction (4); Other (5) 
Appendix 2. Financial value of NTFPs in one hectare of savannah formation

\begin{tabular}{|c|c|c|c|c|c|c|c|c|c|c|c|c|c|c|c|c|c|c|c|c|c|c|c|c|c|}
\hline & \multicolumn{24}{|c|}{ PLOTS (1 ha) } & \multirow{3}{*}{$\prod \mathrm{t}(\mathrm{FCFA} / \mathrm{ha})$} \\
\hline & \multicolumn{2}{|c|}{$n^{\circ} 1$} & \multicolumn{2}{|c|}{$n^{\circ} 2$} & \multicolumn{2}{|c|}{$n^{\circ} 3$} & \multicolumn{2}{|c|}{$n^{\circ} 4$} & \multicolumn{2}{|c|}{$\mathrm{n}^{\circ} 5$} & \multicolumn{2}{|c|}{$n^{\circ} 6$} & \multicolumn{2}{|c|}{$n^{\circ} 7$} & \multicolumn{2}{|c|}{$n^{\circ} 8$} & \multicolumn{2}{|c|}{$\mathrm{n}^{\circ} 9$} & \multicolumn{2}{|c|}{$\mathrm{n}^{\circ} 10$} & \multicolumn{2}{|c|}{$\mathrm{n}^{\circ} 11$} & \multicolumn{2}{|c|}{$\mathrm{n}^{\circ} 12$} & \\
\hline & $\mathrm{T}_{1}$ & $\mathrm{C}_{1}$ & $\mathrm{~T}_{2}$ & $\mathrm{C}_{2}$ & $\mathrm{~T}_{3}$ & $\mathrm{C}_{3}$ & $\mathrm{~T}_{4}$ & $\mathrm{C}_{4}$ & $\mathrm{~T}_{5}$ & $\mathrm{C}_{5}$ & $\mathrm{~T}_{6}$ & $\mathrm{C}_{6}$ & $\mathrm{~T}_{7}$ & $\mathrm{C}_{7}$ & $\mathrm{~T}_{8}$ & $\mathrm{C}_{8}$ & $\mathrm{~T}_{9}$ & $\mathrm{C}_{9}$ & $\mathrm{~T}_{10}$ & $\mathrm{C}_{10}$ & $\mathrm{~T}_{11}$ & $\mathrm{C}_{11}$ & $\mathrm{~T}_{12}$ & $\mathrm{C}_{12}$ & \\
\hline $\begin{array}{c}\text { Value per ha } \\
\text { (FCFA-1) }\end{array}$ & $\begin{array}{l}164 \\
539\end{array}$ & $\begin{array}{c}27 \\
423\end{array}$ & $\begin{array}{l}170 \\
845\end{array}$ & $\begin{array}{c}34 \\
169\end{array}$ & $\begin{array}{l}160 \\
794\end{array}$ & $\begin{array}{l}41 \\
687\end{array}$ & $\begin{array}{l}330 \\
312\end{array}$ & $\begin{array}{c}76 \\
226\end{array}$ & $\begin{array}{l}319 \\
184\end{array}$ & $\begin{array}{c}84 \\
490\end{array}$ & $\begin{array}{l}238 \\
974\end{array}$ & $\begin{array}{c}44 \\
686\end{array}$ & $\begin{array}{l}167 \\
282\end{array}$ & $\begin{array}{c}30 \\
166\end{array}$ & $\begin{array}{l}159 \\
925\end{array}$ & $\begin{array}{c}24 \\
395\end{array}$ & $\begin{array}{l}136 \\
973\end{array}$ & $\begin{array}{c}17 \\
866\end{array}$ & $\begin{array}{l}304 \\
903\end{array}$ & $\begin{array}{c}50 \\
817\end{array}$ & $\begin{array}{l}321 \\
531\end{array}$ & $\begin{array}{c}86 \\
837\end{array}$ & $\begin{array}{l}248 \\
688\end{array}$ & 54400 & \\
\hline П1 (FCFA) & \multicolumn{2}{|c|}{137116} & \multicolumn{2}{|c|}{136676} & \multicolumn{2}{|c|}{119107} & \multicolumn{2}{|c|}{254086} & \multicolumn{2}{|c|}{234694} & \multicolumn{2}{|c|}{194287} & \multicolumn{2}{|c|}{137116} & \multicolumn{2}{|c|}{135530} & \multicolumn{2}{|c|}{119107} & \multicolumn{2}{|c|}{254086} & \multicolumn{2}{|c|}{234694} & \multicolumn{2}{|c|}{194287} & \\
\hline $\begin{array}{l}\text { Value per ha } \\
\text { (FCFA-1) }\end{array}$ & $\begin{array}{l}126 \\
147\end{array}$ & $\begin{array}{c}16 \\
454\end{array}$ & $\begin{array}{l}159 \\
911\end{array}$ & $\begin{array}{c}36 \\
903\end{array}$ & $\begin{array}{l}148 \\
240\end{array}$ & $\begin{array}{c}31 \\
516\end{array}$ & $\begin{array}{l}255 \\
356\end{array}$ & $\begin{array}{c}64 \\
792\end{array}$ & $\begin{array}{l}194 \\
327\end{array}$ & $\begin{array}{c}32 \\
388\end{array}$ & $\begin{array}{l}204 \\
041\end{array}$ & $\begin{array}{c}31 \\
125\end{array}$ & $\begin{array}{l}151 \\
788\end{array}$ & $\begin{array}{c}28 \\
383\end{array}$ & $\begin{array}{l}178 \\
899\end{array}$ & $\begin{array}{c}29 \\
817\end{array}$ & $\begin{array}{l}198 \\
194\end{array}$ & $\begin{array}{c}43 \\
355\end{array}$ & $\begin{array}{l}220 \\
547\end{array}$ & $\begin{array}{c}42 \\
686\end{array}$ & $\begin{array}{l}198 \\
316\end{array}$ & $\begin{array}{c}45 \\
765\end{array}$ & $\begin{array}{l}243 \\
326\end{array}$ & 47095 & 912 \\
\hline П2 (FCFA) & \multicolumn{2}{|c|}{109693} & \multicolumn{2}{|c|}{123009} & \multicolumn{2}{|c|}{116725} & \multicolumn{2}{|c|}{190564} & \multicolumn{2}{|c|}{161939} & \multicolumn{2}{|c|}{172916} & \multicolumn{2}{|c|}{123405} & & & & & & & & & & 6230 & \\
\hline
\end{tabular}

\section{US\$ $1=450 \mathrm{FCFA}$}

Пt : Global Net Market Value (FCFA) +/- Standard Error

$\Pi 1$ and $\Pi 2$ : respectively Net Annual Market Value during year 1 and 2 


\section{REFERENCES}

[1] UN, 1992. A non-legally binding authoritative statement of principles for a global consensus on the management, conservation and sustainable development of all types of forests, New York.

[2] Gopalakrishnan, C., Wickramasinghe, W. A. R., Gunatilake, H.M., Illukpitiya, P., 2005.Estimating the demand for non-timber forest products among rural communities: a case study from the Sinharaja Rain Forest region, Sri Lanka. Agroforestry Systems (65): 13 - 22.

[3] Adger, W. N., Brown, K., Cervigni, R., Moran, D., 1995. Total economic value of forests in Mexico. Ambio, 24: 286296.

[4] Mahapatra, A. K. Tewari, D. D., 2005. Importance of non-timber forest products in the economic valuation of dry deciduous forests of India. Forest Policy and Economics (7), $455-467$.

[5] IIED, 2003. Valuing Forest: A Review of Methods and Applications in Developing Countries. Environment Economics Program. 167p.

[6] Vodouhe, G. F., Coulibaly, O., Greene, C., Sinsin, B., 2009. Estimating Local Values of Non-Timber Forest Products to Pendjari Biosphere Reserve Dwellers in Benin. Economic Botany 63(4): 397-412.

[7] Tewari, D. D., 2000. Managing non-timber forest products as an economic resource. The Journal of Interdisciplinary Economics 11, 269-287.

[8] Anderson, A.B., 1990. Alternatives to Deforestation: Steps toward Sustainable Use of the Amazon Rainforest. Columbia University Press, New York.

[9] Nepstad, C.D., Schwartzman, S., 1992. Non-timber forest products from tropical forests, evaluation and conservation strategy. In: Advances in Economic Botany. Vol. 9, The New York Botanical Garden.

[10] Svarrer, K., Olsen, C.S., 2005. The Economic Value of Non-Timber Forest Products-A Case Study from Malaysia. Journal of Sustainable Forestry, Vol. 20(1) 2005.

[11] Ninan, K. N., 2007. The Economics of Biodiversity Conservation: Valuation in Tropical Forest Ecosystems. Earthscan, 263p.

[12] Vodouhe, G. F. Coulibaly, O., Adégbidi, A., Sinsin, B. Community Perception of Biodiversity Conservation within Protected Areas in Benin. 2010. Forest Policy and Economics 12 (7): 505-512.

[13] Loomis, J.B., 2000. "Can environmental economic valuation techniques aid ecological economics and wildlife conservation" Wildlife Society Bulletin, vol 28, (1), 52-60

[14] Grimes, A., S. Loomis, P. Jahnige, M. Burnham, K. Onthank, R. Alarcon, W. Palacios Cuenca, C. Ceron Martínez, D. Neill, M. Balick, B. Bennett, Mendelsohn, R., 1994. Valuing rain forest: The Economic Value of Nontimber Forest Products in Ecuador. Ambio 23:405-410.
[15] Lawrence, A., Philips, O.L., Ismodes, A.R., Lopez, M., Rose, S., Wood, D., Farfan, A.J., 2005. Local Values for Harvested Forest Plants in Madre de Dios, Peru: Towards a More Contextualised Interpretation of Quantitative Ethnobotanical Data. Biodiversity and Conservation (14):45-79.

[16] IUCN, 2002. IUCN Evaluation of Nominations of Natural and Mixed Properties to the World Heritage List. Report to the World Heritage Committee Twenty-sixth session $24-29$ June 2002 - Budapest, Hungary. Pp. 9-17.

[17] Sodhi, N.S., Acciaioli, G., Erb, M., Tan, A.K., 2005. Biodiversity and Human Livelihoods in Protected Areas: Case Studies from the Malay Archipelago. Cambridge University Press. Pp 478.

[18] Peters, CM., Gentry, A.H., Mendelsohn, R.O., 1989. Valuation of an Amazonian rainforest. Nature 339:655-656.

[19] Chomitz, K. M., Kumari, K., 1998. The domestic benefits of tropical forests: a critical review. The World Bank Research Observer 13(1).

[20] Sheil, D. Wunder, S., 2002. The value of tropical forest to local communities: complications, caveats, and cautions. Conservation Ecology 6(2): 9. [online]

URL:http://www.consecol.org/vol6/iss2/art9.

[21] Pendleton, L.H., 1992. Trouble in paradise: practical obstacles to nontimber forestry in Latin America. Pages 252-262 in M. Plotkin and L. Famolare, editors. Sustainable harvest and marketing of rain forest products. Island Press, Washington D.C., USA.

[22] Godoy, R., Lubowski, R., Markandaya, A., 1993. A method for the economic valuation of non-timber forest products. Economic Botany 47:220-233.

[23] MAB-UNESCO, 1990. Pendjari (Bénin): Contribution aux étudesd'aménagement du Pparc National et de sa zone périphérique. Rapport d'étude. ENGREF/FSA, Cotonou, Bénin.

[24] Brucker, J., 2001: Mission pour l'élaboration du plan d'aménagement de la gestion de la Réserve de Biosphère de la Pendjari. - Projet PENDJARI/CENAGREF, Cotonou, pp: 2-7.

[25] Delvingt, W., Heymans, J.C., Sinsin, B., 1989. Guide du Parc National de la Pendjari. Commission des Communautés Européennes. 125 p.

[26] Adomou, C.A., 2005. Vegetation patterns and; environmental gradients in Benin: Implications for biogeography and conservation. $\mathrm{PhD}$ Thesis. Wageningen University, The Netherlands.

[27] Natta, A.K., 2003. Ecological assessment of riparian forests in Benin. Thèse de doctorat, Université de wagenigen. $215 \mathrm{p}$.

[28] Sinsin, B., Saidou, AA., Tehou, A., Daouda, I. M., Nobime, G., 2000. Dénombrement de la faunedans la réserve de Biosphère de la Pendjari (Rapport technique). Project PENDJARI/CENAGREF/GTZ. 39p. + Annexes.

[29] CENAGREF, 2005. Parc National de la Pendjari, Bénin: Plan d'aménagement participatifet de Gestion 2004-2013. CENAGREF/GTZ, 83 p.

[30] Arbonnier, M., 2000. Arbres, arbustes et lianes des zones sèches d'Afrique de l'Ouest. CIRAD-MNHN, Paris. 
[31] Akoègninou, A., W.J. van der Burg, van der Maesen, L.J.G., 2006. Flore analytique du Bénin. Backhuys Publishers, Leiden, the Netherlands.

[32] Saz-Salazar, S.D., Garcia-Menendez, L., 2001. Willingness to Pay for Environmental Improvements in a Large City: Evidence from the Spike Model and From a Non-Parametric Approach. Environmental and Resource Economics 20: 103-112.

[33] Venkatachalam, L., 2004. The contingent valuation method: a review, Environmental impact assessment review. (24): 89-124.

[34] Adams, C., da Motta, R.S., Ortiz, R.A., Reid, J., Aznar, C.E., de Almeida Sinisgalli, P.A., 2008. The use of contingent valuation for evaluating protected areas in the developing world: Economic valuation of Morro do Diabo State Park, Atlantic Rainforest, São Paulo State (Brazil). Ecological Economics, 66: 359-370.

[35] Chen, W.Y., Jim, C.Y., 2010. Resident Motivations and Willingness-to-Pay for Urban Biodiversity Conservation in Guangzhou (China). Environmental Management 45:1052-1064.

[36] Carson, R. T., 1998. 'Valuation of Tropical Rainforest: Philosophical and Practical Issues in the Use of Contingent Valuation', Ecological Economics 24 (1): 15-29.

[37] Whittington, D. 2010. What Have We Learned from 20 Years of Stated Preference Research in Less-Developed Countries? Annual Review of Resource Economics,2: 209-236.
[38] Whittington, D., Smith, V. K., Okorafor, A., Okore, A., Lium, L. and McPhail, A. 1992. Giving respondents time to think in contingent valuation studies: a developing country application. Journal of Environmental Economics and Management 22: 205-25.

[39] Godoy, R., 1992. Some organizing principles in the valuation of tropical forests. Forest Ecology and Management 50: $174-175$.

[40] Pinedo-Vásquez, M., Zarin, D., Jipp, P., 1992. Economic returns from forest conversion in the Peruvian Amazon. Ecological Economics 6:163-177.

[41] Croitoru, L., 2007. Valuing the non-timber forest products in the Mediterranean region. Ecological Economics 63: $768-775$

[42] Godoy, R., Lubowski, R., 1992. Guidelines for the economic valuation of non-timber tropical forest products. Current Anthropology 33, 423-433.

[43] Lampietti, J., Dixon, J., 1995. To See the Forest for the Trees: A Guide to Non-timber Forest Benefits. Environment Department Papers, Paper, vol. 13. World Bank, Washington DC, p. 32.

[44] Ros-Tonen, M.A.F., 2000. The role of non-timber forest products in sustainable tropical forest management. HolzalsRoh-und Werkstoff 58: 196-201.

[45] Cunningham, A.B., 2001. Applied Ethnobotany: People, wild plant use and conservation. People and Plants Conservation Manual. Earthscan, London. 300 p. 